\title{
Aloe Vera Gel
}

National Cancer Institute

\section{Source}

National Cancer Institute. Aloe Vera Gel. NCI Thesaurus. Code C1565.

A preparation of leaf pulp from the parenchymal tissue of the plant Aloe vera (Liliaceae). Aloe vera gel contains carbohydrate polymers, such as glucomannans or pectic acid, and various vitamins and essential amino acids, as well as other organic and inorganic compounds. This agent has been used internally or externally for sunburn, skin problems, insect bites, ulcers, arthritis, constipation, and as an immune system enhancer. 